\title{
Förkroppsligad pedagogisk takt vid lärares spontana berättande
}

\author{
Ola Henricsson \\ Institutionen för didaktik och pedagogisk profession, Göteborgs Universitet
}

\begin{abstract}
Syftet med studien är att beskriva en lärares spontana berättande och vilka didaktiska innebörder det kan ha. Spontant berättande beskrivs här som en improviserad didaktisk handling med begreppet pedagogisk takt - en lärares kvicka bedömning och spontana handlande, grundat på erfarenhet såväl som känsla, vid oförutsedda händelser i mötet med elever. Ur ett fenomenologiskt perspektiv med fokus på den levda kroppens betydelse analyseras en videoinspelning där en lärare berättar i helklass. I enlighet med kriterier för urval, tidigare analyser av muntligt berättande och för att vara följsam mot fenomenet i tid och rum valdes en lärares berättande ut för djupanalys. I den två minuter långa videosekvensen berättar en lärare, spontant, en anekdot för elever $i$ årskurs sex inom ramen för ämnet teknik. Resultatet visar att lärarens berättande som endast inledningsvis relaterar till ämnet för undervisningen samtidigt har generella didaktiska innebörder då det visar sig som: återhållen undervisning, lyhördhetens oförutsägbarhet och en undervisningens risk.
\end{abstract}

\section{INTRODUKTION}

Kunskapen om och erfarenheten av att exemplifiera och belysa något med anekdoter och berättelser har varit tätt sammanvävt med undervisning genom tiderna. Idag finns det studier som visar att muntligt berättande är en framgångsrik metod vid lärande av såväl första- (Lwin, 2016) som andra språk (Xueping, 2012) och att lärares muntliga berättande hjälper eleverna att kontextualisera, konkretisera och skapa mening åt ämnesundervisningens abstrakta begrepp och metaforer (Bolkan et al., 2020). 
I lärarens förberedelser ingår det, således, emellanåt att planera något att berätta i syfte att gynna elevernas språkutveckling, väcka deras nyfikenhet och intresse men det är också vanligt att lärare berättar improviserat och spontant $i$ anslutning till händelser $i$ mötet med eleverna och ämnet för undervisningen (Bolkan, et al., 2020; Henricsson \& Claesson, 2016, 2019; Kromka, et al., 2020). Lärares spontana berättande, som förefaller fångat i flykten, är inte möjligt att till fullo planera i förväg. Det går inte heller att förutse vilka reaktioner eller interaktioner som kommer att uppstå i mötet med eleverna. Att elevernas interaktion påverkar undervisningen behöver självklart inte vara ett problem utan, tvärtom, en tillgång men $\mathrm{i}$ vår tids målstyrda och prestationsinriktade undervisning och utbildning så tenderar det fria, intuitiva, improviserade didaktiska handlandet $\mathrm{i}$ relation med eleven och ämnet att bortses ifrån (Friesen \& Osguthorpe, 2018; Hopmann, 2007; Koerrenz, 2017). Lärares improviserade och spontana handlande kan beskrivas med begreppet pedagogisk takt (Friesen \& Osguthorpe, 2018; Muth, 1962; Oettingen, 2018). Begreppet användes ursprungligen inom tysk Allgemeine Pädagogik, med rötter i tysk kontinentalfilosofi och bildningstradition. I föreliggande studie används pedagogisk takt som begrepp $\mathrm{i}$ syfte att beskriva didaktiska innebörder av lärares spontana berättande.

Lärarens berättande tolkas här, fenomenologiskt, som en oskiljbar helhet av å ena sidan berättelsens händelseförlopp vilken vi riktar vår uppmärksamhet emot och å andra sidan berättarens röst, blick, hållning, ansiktsuttryck och gester (Young, 1987, 2000, 2011). Den levda kroppen är, generellt, en viktig utgångspunkt i fenomenologiska studier (Hydén, 2008; Merleau-Ponty, 1964; Roth, 2001; Young, 1987, 2000, 2011.) och i föreliggande studie är det specifikt handgester som analyseras. Det bygger vidare på tidigare forskning som betonar gesternas situerade och arbiträra gestaltning sammanvävt med de talade orden i muntligt berättande (Hydén, 2008; McNeill, 1992; Roth, 2001; Young, 2000, 2011).

Inom klassrumsforskning finns en tradition från 1960-talet som studerar lärares kommunikation och det språkspel som uppstår mellan dem och deras elever (Bellack et al., 1966). Mehan (1979) beskrev den här typen av kommunikativa undervisningshandlingar, vilka vanligtvis inte finns $i$ andra sammanhang än i undervisning, som I-R-E. I står för initiation, R-för respons och E för evaluation. Läraren initierar en fråga, eleverna svarar och läraren utvärderar. I en omfattande studie om lärares kommunikationsformer beskriver Alexander (2001) framför allt två: läxförhör och recitation - där läxförhöret handlar om kontroll av elevers kunskaper och recitationen en kommunikationsform bestående av frågor och svar i syfte att bygga upp en fördjupad förståelse eller en gemenskap kunskap. Det finns en asymmetri vad gäller tolkningsföreträde där lärarens tal beskrivs som en monologisk framställning där eleverna inte är delaktiga till skillnad från en dialogisk undervisning (Aasebø et al., 2017). Ingen av de nämnda kommunikations- 
formerna beskrivs eller tolkas ur ett fördjupat narrativt perspektiv på lärares muntliga berättande. Möjligen kan berättande rymmas inom ramen för en recitation men muntligt berättande är en unik form av muntligt tal med specifika kvaliteter som tidigare forskning visat (se Bamberg \& Demuth, 2016; Barkhuizen, et al., 2014; McEwan \& Egan, 1995; Riessman, 1993; Young, 1987, 2000, 2011).

Syftet med studien är att ur ett fenomenologiskt perspektiv beskriva hur en lärares improviserade och spontana berättande visar sig, samt att diskutera vilka didaktiska innebörder det kan ha.

\section{RAMVERK}

I följande avsnitt presenteras inledningsvis tidigare forskning om muntligt berättande som rör vardagligt återberättande av specifika händelseförlopp ur ett fenomenologiskt perspektiv med utgångspunkt i den levda kroppen. Därefter redovisas tidigare forskning som rör lärares spontana didaktiska handling här benämnd som pedagogisk takt. Sammantaget syftar det till att ge en bakgrund till studiens undersökning av lärares spontana muntliga berättande i undervisning.

\section{Muntligt berättande}

Lärares spontana vardagsberättande ses i föreliggande studie som "event narratives" (Andrews et al., 2008) och kan beskrivas som "muntligt tal om specifika händelser" (s. 8). ${ }^{1}$ Den här typen av studier av vardagligt berättande bygger vidare på Labovs sociolingvistiska forskning från slutet av 60-talet. När Labov (1972) genomförde sin studie av ungdomars vardagsberättande var han pionjär inom ett litet fält av studier på muntliga berättelser, som formligen skulle explodera under årtiondena som följde. "The narrative turn", som vändningen att använda berättelser som metod och material inom ett stort antal vetenskapliga discipliner kom att kallas, inleddes i stor omfattning på 1980-talet (Bamberg \& Demuth, 2016). McEwan \& Egan (1995) är exempel på narrativa studier specifikt inom området för undervisning, lärande och forskning.

Young (1987) vidareutvecklade Labovs strukturella analys av muntligt berättande utifrån ett fenomenologiskt perspektiv där hon beskriver upplevelsen av muntligt berättande med begreppen realm of conversation, storyrealm och taleworld. I Palmenfelts (2006) svenska översättning blir begreppen; konversationens rike, berättandets rike och berättelsens värld. I den här studien beskriver konversationens rike den muntliga interaktion som sker i undervisningssituationen $\mathrm{i}$ anslutning till att läraren väljer att berätta. När lärare eller elev inom ramen för konversationens rike återger ett händelseförlopp öppnas, följaktligen, berättandets rike, som i sin tur skapar ramarna 
för och möjligheterna att levandegöra berättelsens värld. I berättelsens värld riktar vi som lyssnare hela vår uppmärksamhet på det återberättade händelseförloppet "som-om" det utspelades i ett här och nu samtidigt som vi befinner oss på en reflekterande distans till händelseförloppet som återberättas. Som lyssnare vänder vi oss inåt mot självreflektion samtidigt som vi upplever berättandet tillsammans och i närhet med andra. Vi upplever berättelsens händelseförlopp genom vår föreställningsförmåga samtidigt som vi upplever den i berättarens röst, ansiktsuttryck, gester och hållning. I den här studien används också begreppet coda från Labovs analys (1972) som beskriver den avrundande sekvens i vilken berättaren lämnar över till lyssnare att kommentera, fråga eller fortsätta.

När vi berättar till vardags skapar vi berättelser baklänges, för att följa filosofen Ricœur (1980). Vi utgår från händelser som en gång väckt vår uppmärksamhet, berört oss, utifrån dem återskapar vi sedan en början. Ricœur betonar att berättelsens början är starkt förbunden med, och styrd mot, slutet. Ochs och Capps (2001) påpekar att vardagsberättande handlar om händelser som redan inträffat men som samtidigt upplevs i ett berättande nu och som i sin tur alltid är riktat mot framtiden. Således argumenterar Ochs och Capps (2001) att vår upplevelse av tid, i vardagsberättande, är "icke-linjär på så vis att det förgångna, nuet och framtiden upplevs holistiskt" (s. 157). Young (2000) uppmärksammar, på samma sätt, att berättande inte "återkallar känslor från det förflutna eller ur vårt undermedvetna" (s. 81) utan snarare skapas i ett berättande nu - i den levda kroppen.

Att förstå muntligt berättande som ett socialt och mellankroppsligt fenomen leder över till att erkänna den levda kroppens betydelse i sammanhanget. Kroppens betydelse har utelämnats eller förminskats i tidigare narrativ forskning (Ochs, 1979). Hydén (2008) visar att om kroppen finns nämnd i studier är det $\mathrm{i}$ form av representationer som att till exempel kroppsdelar används som metaforer för något annat. Eftersom det är det spontant levandegjorda berättandet som är studieobjektet i detta fall blir intersubjektivitet eller snarare interkorporealitet, den andres levda kropp, centralt i denna studie. Vad berättarsituationen kan betyda för lyssnare och berättare ur ett emotionellt och personligt perspektiv kan belysas med hjälp av begreppet interkorporealitet, som Merleau-Ponty (1968) utvecklade utifrån begreppet intersubjektivitet i syfte att betona den levda kroppens betydelse $\mathrm{i}$ interaktion och perception. Det betyder att ett interkorporiellt perspektiv på muntligt berättande ger bilden av ett sammanvävt och ibland också motsägelsefullt fenomen. I förståelsen av att vi är kulturellt och socialt erfarna kroppar får det kroppsligt levandegjorda berättandet vetenskaplig signifikans och Merleau-Ponty (1999) uttrycker det som att "man hör sig själv i den andre och att den andre talar i mig" (s. 47).

Lärares användning av gester vid kroppsligt levandegjort berättande i undervisning är ur detta perspektiv av betydelse för hur elever skapar 
förståelse och mening. Enligt Roth (2001) kom eleverna ihåg berättelser i större omfattning om lärare använde medvetna såväl som omedvetna gester än om de inte använde gester. Gester konkretiserar och gestaltar berättelsens händelseförlopp, karaktärers handlande och känslor på ett direkt, spontant och intuitivt sätt. Young (2011) menar att en berättares spontana gester visualiserar - ger spatial och temporal gestalt åt - händelseförlopp i berättelsen men att berättaren är lika omedveten om sina egna gester som att lyssnaren tolkar dem som meningsfulla. Gesterna ses som sammanvävda med de talade orden, inte som ett komplement till dem, och som samtidigt bär sin unika mening vid muntligt berättande (McNeill, 1992).

Sammanfattningsvis är lärares muntliga berättande ett komplext och samtidigt vardagligt fenomen som naturligt förekommer i undervisningssituationer. Komplexiteten ligger i det muntliga berättandets fenomenologi, med rumsliga, kroppsliga och relationella aspekter, där det sammanvävda berättandet och berättelsen utgör en helhet och ibland med motsägelsefulla upplevelser (Merleau-Ponty, 1964). Berättandet levandegörs kroppsligt med berättarens röst, ansiktsuttryck, gester och hållning som tillfälliga och reciproka uttryck samtidigt som lyssnaren skapar inre bilder av händelseförloppet med sin föreställningsförmåga.

\section{Pedagogisk takt och den didaktiska triangeln}

Lärares berättande i undervisning visar sig, fenomenologiskt, som ett mellanmänskligt möte och följaktligen också som en ömsesidig, spontan och improviserad didaktisk handling. I det här avsnittet presenteras inledningsvis den didaktiska triangeln och därefter utreds begreppet takt för att belysa samspelet mellan lärare, elev och ämne vid berättande $\mathrm{i}$ undervisning.

Den didaktiska triangeln beskriver, i sin enklaste form, undervisning med läraren, eleven och ämnet $i$ var sitt hörn av triangeln. Undervisning kännetecknas av relationer mellan lärare, elev och ämnesinnehåll och triangeln är en modell för att illustrera hur olika didaktiska val och handlingar påverkar balansen i triangeln. Undervisning kan omöjligt beskrivas utan att relationen mellan lärare, elever och innehåll presenteras. Däremot kan, exempelvis, lärande beskrivas som en endimensionell relation mellan innehåll och elev. Undervisning implicerar en påverkan utifrån, från läraren (Biesta, 2012; Oettingen, 2018), eller elevens önskan om påverkan utifrån (Friesen, 2017). Friesen och Osguthorpe (2018) menar att spontan didaktisk handling kan beskrivas som ett försök att balansera mellan de olika hörnen i den didaktiska triangeln och menar att takt kan användas för att illustrera den handlingen. De beskriver takten som tvådelad - dels som ett taktfullt handlande gentemot eleverna, dels som en taktfull undervisning av ämnets innehåll. Friesen och Osguthorpe (2018) uttrycker det som att: "En lärare måste kunna skilja på en elev och hennes prestationer och förmågor" (s. 262). Det här tudelade perspektivet behöver balanseras av lärarens pedagogiska takt, menar för- 
fattarna, annars "kollapsar den didaktiska triangeln till en endimensionell enkelriktad linje" (s. 262) från elevernas brister till det föreskrivna målet för undervisningen. Med den didaktiska triangeln kan berättandets levda aspekter och hur de ger innebörd åt ett ämnesinnehåll för lärare och elever illustreras (Figur 1). Hopmann (2007) stryker under att det kan finnas olika innebörder av ett givet innehåll. Innebörder skapas i mötet mellan lärare, elev och ett innehåll (s. 116).

Figur 1. Den didaktiska triangeln.

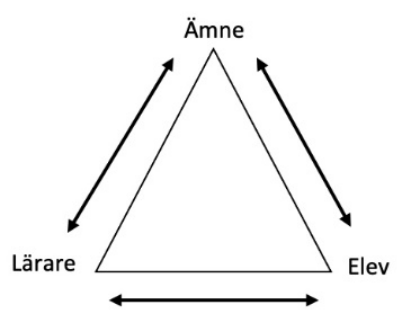

Redan vid sin installationsföreläsning 1802 vid Universitet i Jena introducerade Herbart begreppet pedagogisk takt ${ }^{2}$ för att beskriva lärares kvicka bedömning och spontana handlande, grundat på erfarenhet såväl som känsla, vid oförutsedda händelser i mötet med elever (Muth, 1962). Herbart beskrev det som att handlingen grundar sig på såväl praktisk-didaktisk erfarenhet som på teoretisk-didaktisk kunskap. Begreppet användes under 1800-talet men föll i glömska under 1900-talets första hälft. Van Manen $(1991,2014,2015)$ har på senare år återupptagit begreppet och beskriver takt ur ett etiskt perspektiv som en lärares intuitiva finkänslighet för ett enskilt barns behov i specifika situationer. Van Manen (2015) betonar i sin utredning av takt att det varken kan definieras som teori eller praxis och inte heller som något obestämt som ligger mellan teori och praxis och därför behövs ett annat, nytt språk, för att beskriva fenomenet. Kritiker av van Manens hävdar att en beskrivning av pedagogisk takt som det normativt goda kan leda till en idealiserad och oreflekterad hållning (Colnerud, 1997; Tjärnstig, 2020). Eriksson (1999) tolkar van Manens beskrivning av takt som att vilja lyfta essensen av vad som kännetecknar den "goda läraren". Vidare menar Westfall-Greiter och Schwarz (2012) att van Manen varken erbjuder beskrivningar av pedagogisk takt i förhållande till helklassundervisning eller $\mathrm{i}$ förhållande till undervisning av ett specifikt ämnesinnehåll. Det är för övrigt en kritik som även begreppets upphovsman Herbart fått. Westfall-Greiter \& Schwarz (2012) menar, i Herbarts fall, att det har att göra med hans egna empiriska erfarenheter som härrör från privat hemundervisning i priviligierade hushåll. De menar att den en-till-en-undervisning, som Herbart skriver om, knappast är aktuell $i$ vår tid 
och att det är svårt att förena med skolans institutionella kontext. I van Manens fall visar sig denna brist i hans återkommande jämförelser mellan undervisning och att som förälder uppfostra sina barn.

Ett betydligt mer explicit didaktiskt klassrumsperspektiv på begreppet takt väljer Muth (1962) i sin avhandling, Pädagogischer Takt. Han beskriver fenomenet utifrån två skilda meningshorisonter ${ }^{3}$ dels som ett fenomen som visar sig $\mathrm{i}$ förhållande till utbildning av barn och unga, dels som ett fenomen $\mathrm{i}$ undervisning av barn och unga som didaktisk handling. Föreliggande studie analyserar och diskuterar lärares berättande som en didaktisk handling utifrån tre aspekter av pedagogisk takt; lyhördhet ${ }^{4}$, återhållsamhet ${ }^{5}$ samt en undervisningens risk (Muth, 1962).

Lyhördhet, en grundaspekt av takt, kan beskrivas som en lärares känsla för vad som är rätt för just de här eleverna i den här situationen i förhållande till ämnet för undervisningen, enligt Muth (1962). Återhållsamhet, den andra grundläggande aspekten, förstår Muth som en aktiv-passiv hållning. Att avvakta och träda tillbaka ska förstås som att skapa förväntningar på elevens självverksamhet och är motsatsen till att lämna någon i sticket eller att inte bry sig. Tvärtom är en återhållen undervisning beroende av elevens behov och uttryck och inte sprunget ur lärarens vilja att hålla distans (s. 56). Det leder till en icke-påflugen undervisning, enligt Muth, där elevernas oförutsedda och spontana intressen och engagemang för ämnet får utrymme och där läraren inte endast har elevens prestation eller undervisningens mätbara resultat $\mathrm{i}$ åtanke. Muth liknar elevernas faktakunskaper vid främmande städer som de besöker. Lärarens pedagogiska takt beskriver Muth som att våga ta risken att barnet går vilse men också kunna leda dem tillbaka till tidigare kända gator (s. 98).

Eftersom spontan undervisning inte kunde standardiseras bestämdes tidigt inom den kontinentala didaktiken att takt skulle vara ledande för improviserade undervisningsformer (Muth, 1962), till exempel förmågan att fånga tillfället i flykten och skapa en händelse i undervisning av ett ämnesinnehåll. Att fånga ett ögonblick kräver träning och förberedelser. Att taktfullt handlande inte går att planera eller bestämma i förväg innebär inte att det går att strunta $\mathrm{i}$ att förbereda sig utan tvärtom att planera det som är möjligt att planera och "förvänta sig det oförväntade" (Westfall-Greiter \& Schwarz, 2012, s. 132). Takt visar sig inte bara i språkets innehåll utan även i en lärares blick, gester och närvaro. Friesen (2018) analyserar en undervisningssituation där en lärares handlande visar sig som pedagogisk takt i gester, hållning och ansiktsuttryck. Han menar att takt även kan gestaltas som en lärares knutna näve när ett kärleksfullt och mjukt knytnävsslag används för att väcka en kämpande elev som läraren har omsorg för.

Det är i det oförutsägbara mötet med eleverna undervisningens risk visar sig. En påflugen undervisning, i vilken läraren leder eleverna efter en steg-försteg-metod utan att ge eleverna något spelrum, innebär sällan någon risk. 
Biesta (2013) skriver att undervisningens risk visar sig när elever ses som handlande och ansvarstagande subjekt och att risken finns där eftersom undervisning inte är interaktion mellan robotar utan ett möte mellan människor (s. 1). Att undervisa är en långsam, frustrerande och svår väg, menar Biesta och att resultatet med en sådan här "svår väg, frustrerande väg och, låt oss säga, ömtålig väg” (s. 3) varken går att garantera eller säkra. Biesta (2013) menar att kreativitet inte bör handla om att skapa och reproducera ett förutbestämt innehåll utan snarare är en förmåga att skapa mening åt händelser och situationer. I linje med detta diskuterar Hopmann (2007) att lärarens didaktiska frihet är avgörande för att kunna ge eleverna möjlighet att skapa mening åt ett ämnesinnehåll. Sambandet mellan mening och innehåll är inte ett ontologiskt eller ideologiskt faktum utan det visar sig snarare som en erfarenhet som uppstår i varje unik situation och är därför omöjlig att planera på förhand (s. 117). På det viset kan lärares spontana och improviserade berättande sägas vara en kreativ didaktisk handling i syfte att öppna för elevernas meningsskapande som konstitueras som oförutsägbart.

Sammanfattningsvis visar sig pedagogisk takt som en lärares spontana och improviserade handlande i en uppkommen undervisningssituation i relation till eleverna samt ämnesinnehållet. Takt kan också beskrivas som lärarens spontana handlande i syfte att hitta balansen mellan hörnen i den didaktiska triangeln (Friesen \& Osguthorpe, 2018). Enligt Muth (1962) är återhållsamhet och lyhördhet två grundläggande aspekter av takt som dessutom kännetecknas av en undervisningens risk. Pedagogisk takt ses här inte som något givet gott - en essens av normativt handlande - utan snarare som en lärares lyhörda, återhållsamma och frihetliga didaktiska handlande.

\section{METOD OCH MATERIAL}

I det här avsnittet beskrivs hur det empiriska materialet har skapats, hur urval, transkriberingar och analysen har genomförts. Det avslutas med en etisk reflektion.

\section{Material, urval och transkribering}

För att få tillgång till lärarnas förkroppsligade spontana berättande med exempelvis gester, hållning och ansiktsuttryck vid sidan av det verbala språket valdes deltagande observation och ljud- såväl som audiovisuella inspelningar som materialinsamlingsmetoder (Derry, 2007; Rödel \& Brinkmann, 2018). Den videosekvens som är föremål för analys i föreliggande studie valdes ur ett större material med videoinspelningar av lärare som berättar. Det resterande empiriska materialet är tänkt att användas för fortsatta studier. I enlighet med kriterier för urval, tidigare djupanalyser av muntligt berättande som en helhet (Young, 2000) och för att vara följsam mot fenomenet $i$ tid och 
rum (Bengtsson, 1999; Claesson \& Rinne, 2019) valdes en lärares berättande ut för fortsatt analys. Sekvensen består av lärare Helens berättande i årskurs sex under en lektion i teknik och är två minuter lång. För att illustrera hur ett fenomen visar sig kan en enskild videosekvens, eller till och med en del av en videosekvens, väljas ut vid analys. Derry (2007) betonar att kriterier för urvalet bör vara dess unika rikedom att representera och illustrera fenomenet men framför allt dess förmåga att exemplifiera fenomenet (s. 19). I fenomenologiska studier används ibland anekdoter eller vinjetter (Schratz et al., 2012) som täta och innehållsrika berättelser för att exemplifiera ett specifikt fenomen. Forskaren söker fånga det enskilda tillfället - "die Momente" - där fenomenet visar sig (Schratz et al., 2012, s. 35).

Inledningsvis identifierades händelsebaserade anekdoter - events narratives (Andrews et al., 2008) i det empiriska materialet i syfte att urskilja berättelser och berättande om specifika händelser i lärarnas tal. Lärarens berättande skulle följaktligen bestå av en berättelse från början till slut i sin helhet (Labov, 1972; Young, 1987). Innehållet i lärarnas tal som kunde identifieras som muntligt berättande transkriberades med såväl innehåll, ansiktsuttryck, hållning som gester. Dels för att explicera specifika gester och handlingar, dels för att generellt illustrera det levda berättandet, används tecknade illustrationer från den inspelade videosekvensen. Lärares beskrivande, informerande, tillrättavisande, frågande och svarande tal har i regel inte transkriberats eller analyserats. Lärares högläsning och refererande till berättelser har inte heller transkriberats i sin helhet då de inte kännetecknas av samma kvalitativa egenskaper som muntligt berättande (Young, 1987).

\section{Analys}

Analys och tolkning av den valda sekvensen genomfördes i syfte att skapa en tät beskrivning (Derry, 2007) av en unik berättarsituation (Young, 1987, 2000, 2011). Den första analysen genomfördes genom att urskilja fenomenet berättande i klassrumskonversationen. En andra analys gjordes vid transskriberingen av det kroppsligt levandegjorda berättandet med såväl tal som gester. Därpå analyserades specifikt lärarens berättande ingående och i detalj - dels utifrån pedagogisk takt som didaktisk handling (Muth, 1962), dels utifrån Katharine Youngs fenomenologiska analys av berättandets upplevelsevärldar och berättande som levd kropp (Merleau-Ponty, 1964, 1968; Young, 2011) - i huvudsak med studier av gester (Hydén, 2008; McNeill, 1992).

Analysen av lärarens gester följer McNeills taxonomi (1992): ikoniska (iconic), metaforiska (metaphoric), pekande (dietics) och rytmiska (beats). Ikoniska gester - föreställande gester - gestaltar föremål som nämns eller används eller handlingar som utförs av karaktärerna i berättelsen. De används frekvent i muntligt berättande mer vanligt när berättaren gestaltar berättelsens värld "som-om" händelseförloppet utspelades mellan berättare och lyssnare i 
vad McNeill (1992) benämner som gesture space. Metaforiska gester är gester som en gång varit föreställande, som ikoniska gester (Young, 2011), men fått en överförd betydelse som metafor för något annat. En vanlig metaforisk gest är att hålla handflatorna öppna en bit ifrån och samtidigt vända mot varandra. McNeill benämner den container gesture - innehållsgest. Gesten gestaltar ett innehåll, ursprungligen ett konkret innehåll. Rytmisk gest används för att markera, stryka under vissa ord eller händelser. I undervisning är pekande gester vanligt (Roth, 2001; Rödel \& Brinkmann, 2018) då eleverna ska göras uppmärksamma på föremål och företeelser såväl i den faktiska verkligheten som på kartor och andra illustrationer och även mot gestaltade föremål och händelser i berättelsens värld.

Videoinspelningen gav möjligheter att identifiera och belysa innebörder i de gester och de ansiktsuttryck som lyssnaren vanligtvis registrerar och tolkar som en immanent del av muntligt berättande (Young, 2011). Videoinspelningen gav också möjlighet att spela upp situationen upprepade gånger och i olika hastighet för att undvika misstolkningar och oklarheter (Rödel \& Brinkmann, 2018).

\section{Etisk reflektion}

Lärare, elever och deras vårdnadshavare har informerats om studiens fokus, lärares tal, och givit sitt samtycke till ljud- och videoinspelning av lärares undervisning $\mathrm{i}$ helklass. Lärarna hälpte till att förmedla och samla in samtyckesblanketter. Lärare och elever har pseudonymiserats i såväl text som bild och på det sättet avidentifierats (Vetenskapsrådet, 2017). Transskriberingarna av videoobservationerna har vid tillfälle visats för deltagande lärare. Att presentera det empiriska underlaget för deltagarna gav dem möjlighet att kommentera eventuella missförstånd och förmedla sina tankar om transkriberingarna (Miller, 2012). Deras kommentarer och respons har inte vidare använts i studien som empiriskt underlag vid analys eller tolkning utan endast varit av etiska skäl.

\section{ANEKDOT OM EN TYST MINUT FÖR EN KASTAD KRUKVÄXT}

Resultatbeskrivningen nedan följer berättarsituationen från början till slut. Upplevelsen av berättandet gestaltas och analyseras under fyra olika rubriker: konversationens rike, berättandets rike, berättelsens värld och coda. I konversationens rike länkar läraren berättandet till ämnet $\mathrm{i}$ en fråga/svaraktivitet innan hon upprättar berättandets rike genom att gå från det abstrakta till det konkreta - från det generella till det unika. Hon gestaltar därefter händelser inifrån berättelsens värld ur karaktärsperspektiv som om den omslöt oss som lyssnar. Codan avslutar och återför berättarsituationen till konversationens rike. För att visualisera lärarens berättande som levd kropp 
och didaktisk handling används illustrationer från videoinspelningen som exempel under varje rubrik.

\section{Konversationens rike}

Läraren $i$ årskurs sex har planerat en lektion om programmering inom ramen för ämnet teknik och som inledning har hon förberett en berättelse om Ada Lovelace och världens första dator. Innan hon börjar med den förberedda berättelsen berättar hon ett minne och det är den anekdoten som är fokus i föreliggande analys. De 24 eleverna kommer in i klassrummet för att sätta sig i bänkar vända framåt och grupperade två och två. Det är ljudligt och pratigt men läraren väntar tills alla elever satt sig ned och säger sedan till dem att vara tysta. Det blir de inte utan de fortsätter prata och läraren får säga till dem ytterligare en gång. En av eleverna påpekar då att hon bara pratar med blommorna i fönstret. Läraren plockar snabbt upp tråden och börjar spontant berätta om en krukväxt hon hade under förra året $i$ en parallellklass. Hon samlar eleverna och får dem att lyssna. Plötsligt pausar läraren berättelsen och länkar den till, ett för klassen känt, ämnesinnehåll genom att repetera fotosyntesen i en fråga/svar-aktivitet i helklass.

\section{$1 \mathrm{~L}: \underline{\text { Ni vet att man ska prata med växter, va?6 }}$ \\ Ler och pekar ömsom på sig själv och växterna i fönstret och övergär till en gest med en något öppen och kupad handflata vänd uppàt $i$ vänstra handen "som-om" hon böll $i$ blomman.}

2 L: Varför skulle man prata med växter nu då?

Håller vänsterhandens handflata fortfarande vänd uppåt tydligt kupad "som om" hon höll krukväxten och höger hand öppen ut mot elever.

Figur 2. Varför skulle man prata med växter nu då?

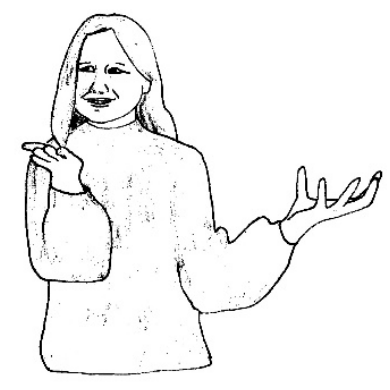

3 E: ---- (Hörs inte på grund av småprat från flera elever) 
$4 \mathrm{~L}: \mathrm{Ssch}$ !

$5 \mathrm{E}:$ De får syret...eller de får koldioxiden som man andas ut.

6 L: De får kold...precis...Maria och...ni får gärna prata men inte så högt med växten...ok?

Rör sig mot eleverna som pratat men häller fortfarande vänster hand som om hon böll $i$ krukväxten.

7 L: Eh...

Pekar ömsom mot sin egen mun och vänster hand.

$8 \mathrm{~L}: \mathrm{Ja}$, precis, då får den ju mitt koldioxid och vad får jag från växten?

Leende och höjda ögonbryn pekande mot en elev med öppen hand.

9 Elever: Syre!

10 L: Syret ja!

Analys: Läraren fångar tillfället i flykten och elevernas uppmärksamhet genom att börja berätta om en krukväxt. Elevens yttrande att hon pratar med blommor väcker lärarens minne av en händelse som berört henne (Ochs \& Capps, 2001; Ricœur, 1980). Att eleverna tystnar och lyssnar tolkas som att berättande skapar en förväntan på att få uppleva ett händelseförlopp till skillnad från, exempelvis, tillsägelse eller instruktion. Läraren tar kontroll över situationen och visar en pedagogisk lyhördhet att med berättande fånga elevernas uppmärksamhet. Att hon avbryter berättandet och länkar det till undervisningen $i$ en utvikning av repetitionsfrågor om fotosyntesen ses som en annan aspekt av pedagogisk lyhördhet $\mathrm{i}$ syfte att rikta elevernas uppmärksamhet mot ämnet för undervisning. Friesen och Osguthorpe (2018) kallar det här handlandet för att balansera i den didaktiska triangeln mellan å ena sidan eleverna och å andra sidan ämnet för undervisningen. Lärarens gester exemplifierar den mellankroppsliga dimensionen av berättande då samtidiga gester, med olika innebörd, sammanvävs till en helhet. $\AA$ ena sidan uppmuntrar de metaforiska gesterna, som läraren utför med höger hand, eleverna att delta i en fråga/svar-aktivitet ( $\operatorname{rad} 2$ och 8$)$. $\AA$ andra sidan utför hon en ikonisk gest med vänster hand "som om" hon konkret håller krukväxten i sin hand. Den senare kan tolkas som att berättelsen, i vilken gesten introducerades, bara pausat och snart kommer att återupptas.

\section{Berättandets rike}

Efter den inledande repetitionen, i konversationens rike, fortsätter läraren genom att öppna berättandets rike. Hon beskriver föremål och karaktärer, tid och rum, och det bildar en bakgrund för händelserna som hon förväntas återge $\mathrm{i}$ berättelsens värld. 


\section{$11 \mathrm{~L}: \underline{\mathrm{Och}}$}

Höger pekfinger uppsträckt framför kroppen signalerar uppmärksambet.

12 L: Så jag började prata med den här

Riktar högerhandens pekfinger mot vänster hand.

13 L: och det här blev min kompis och så då bestämde jag mig för att ge den ett namn och då var det faktiskt Åke som hade namnsdag den dagen

Stär still med vänsterbandens kupade gest oförändrad.

14 Elever: (hummar och fnissar)

Figur 3. / .../ då var det faktisket Ake som hade namnsdag den dagen.

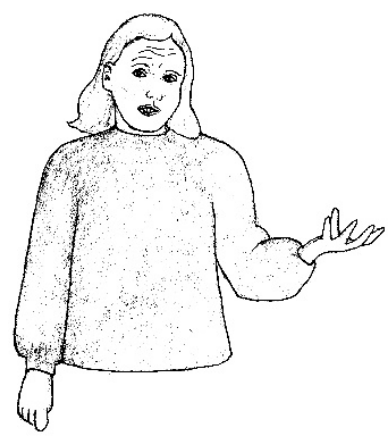

15 L: Så den fick heta $\underline{\AA \mathrm{ke}}$

Markerar "Ake" genom en snabb rörelse med vänsterhanden ner och upp.

16 L: och så stod den här

$V$ isar med båda bänderna hur hon ställer undan krukväxten mot en bänk $i$

klassrummet och släpper för första gången på 30 sekunder gesten med krukväxten.

17 E: Och dog?!

18 L: Nej, den levde faktiskt hela terminen

Lyfter upp högerhands pekfinger på "nej" och skrattar.

Analys: Läraren fångar på nytt upp berättelsen och eleverna, efter utvikningen i konversationens rike, genom att rikta uppmärksamheten mot sin öppna vänstra hand. Hon går nu från det generella talet om växter och fotosyntesen och riktar uppmärksamheten mot berättandets rike och den unika krukväxten Åke. Att läraren håller gesten med krukväxten i hela 30 sekunder tolkas som ett uttryck för lyhördhet och gestaltar berättandets reciproka aspekt. Hon förkroppsligar berättelsen i närvaro och med timing. Eleverna fnissar, hummar och föreslår i ett fall även en fortsättning på händelseförloppet. 
Läraren svarar på den drastiska kommentaren "och dog?!" med ett skratt. Hon genomför en gest som att hon ställer ifrån sig "krukväxten" på en bänk $i$ klassrummet och använder på det viset det faktiska klassrummet och bänken som metafor för berättelsens klassrum. Gesten illustrerar hur det muntliga berättandet visar sig som holistiskt genom att de båda rummen smälter samman till en helhet av då och nu (Ochs \& Capps, 2001).

\section{Berättelsens värld}

Efter att hon kort berättat hur hon till slut slängde krukväxten då den blev full av ohyra öppnar hon berättelsens värld ( rad 19) och berättar vad som hände när eleverna återkom efter sommarlovet. Efter en kort paus ( $\operatorname{rad} 21)$ sätter hon berättelsens tid i rörelse genom att citera en elev.

19 L: Så hade vi gått nån vecka i skolan eller nåt och så satt vi på en vanlig mattelektion och så där

Stär still med knutna bänder framför kroppen och rör buvudet lite àt höger på "mattelektion".

20 L: och då sa Wilma plötsligt

Tonar ner sin röst och tar ner tempot nagoot inför citatet.

$21 \mathrm{~L}:$ (Paus, 0,4 s)

Gör en kort paus innan hon gestaltar Wilmas fråga.

22 L: "Men var är Åke?"

Citerar en elev och slàr ut med armarna och bänderna upp med öppna handflator $i$ vinklar snett utät och uppät och blicken uttrycker förvaining och oro.

Figur 4. "Men var är Ake?"

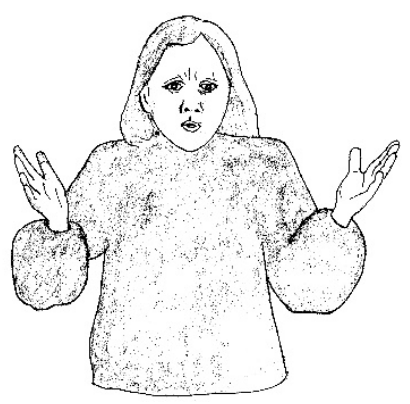

23 Elever: (Hummar och fnissar).

$24 \mathrm{~L}: \underline{\text { Sa hon }}$

Leende. 
25 L: Och då var jag tvungen att berätta: "Jag kommer tyvärr... det är lite sorgligt men"

Markerar "berätta" och "tyvärr" med båda bänderna och med handflatorna fortfarande vinklade uppàt. Rör höger hand genom häret på "det är lite sorgligt men".

26 L: "Men"

Flyttar höger hand till under hakan och båller pekfinger och tumme mot hakan. 27 L: "Åke"

Markerar "Ake" med ett slag med höger band innan den faller ned och ut ur gest som en markering.

28 L: (Paus, 0,6 s)

29 L: "Har flyttat till himlen"

Ihopdragen mun synligt leende men $i$ örrigt stilla.

30 Elever: (skrattar och fnissar)

31 L: "Han lever inte bland oss längre" och då sa Wilma

Innehällsgest - bändernas handflator vända mot varandra markerar pà "Wilma".

32 L: (Paus, 0,6 s)

33 L: "Vi får ha en tyst minut för Åke"

Lyfter böger pekfinger som övergår $i$ en öppen handflata utàt.

Figur 5. "Vi fär ha en tyst minut för Ake".

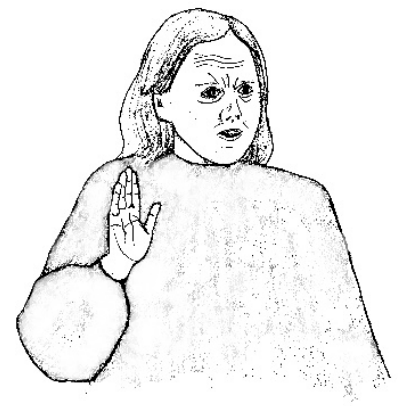

34 Elever: (Skrattar och fnissar)

$35 \mathrm{~L}:$ Och alla var med på det

Slàr ut med armarna inifrän och ut àt sidorna - småskrattande.

36 L: Och jag tänkte "Yes!"

Knyter händerna vid buvudet som en segergest. 
Figur 6. Och jag tänkte: 'YYes!".

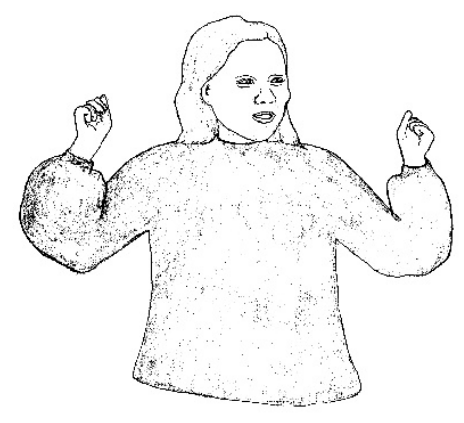

37 L: "En tyst minut", tänkte jag,

Markerar "tyst" med båda bänderna i gesten.

38 L: "för det är inte så vanligt".

Innehällsgest som markerar "inte".

39 Elever: (Skrattar och fnissar)

40 L: $\underline{\text { Så }}$

Lyfter innebällsgesten och häller båda bändernas handflator mot klassen och markerar "Sä" innan hon sätter händerna i sidorna och nickar.

Analys: Läraren byter berättarperspektiv och återger berättelsens värld ur ett karaktärsperspektiv och låter berättelsens tid och rum omsluta oss. I denna korta sekvens levandegör läraren berättelsens värld explicit med de talade orden och kroppen sammanvävda vilket är vanligt i vardagligt berättande (Ochs \& Capps, 2001; Young, 2000, 2011). Läraren modulerar röstens tempo och ton och använder pauser. Hon utför ikoniska, metaforiska och rytmiska handgester och visar ansiktsuttryck och beskriver känslor, förvåning, undran och glädje. Hon använder kroppens hållning och riktning genom betydelsebärande växling mellan rörelse och stillastående exempelvis när hon, ur ett karaktärsperspektiv som sig själv i berättelsen, stillastående meddelar att krukväxten dött och på det viset gestaltar en känsla av allvar som förstärker det komiska i situationen. Den här något tekniska beskrivningen av kroppens gestaltning vid berättandet illustrerar det muntliga berättandets sammanvävda helhet av det talade ordet och den levda kroppen (Merleau-Ponty, 1999; Young, 2000, 2011). Här tolkas lärarens berättande som att hon gör sig tillgänglig, synlig och tydlig för eleverna. Samtidigt som hon leder eleverna i berättelsens värld finns en motsägelsefull upplevelse av frihet eftersom eleverna själva ger mening åt berättandet (Muth, 1962). Således tolkas här 
muntligt berättande i undervisning, utifrån berättandets fenomenologi, som ett återhållsamt sätt att undervisa $\mathrm{i}$ den bemärkelsen att berättande nödvändigtvis gestaltar ett händelseförlopp som var och en av eleverna upplever och tolkar själva. Mot slutet av sekvensen, kommenterar läraren berättelsens händelseförlopp, utifrån sig själv som en karaktär i berättelsen, och utför en segergest och säger att en tyst minut inte var så vanlig i den klassen. Att eleverna skrattar åt lärarens kommentar, i form av en metanarrativ, kan tolkas som att läraren och eleverna har gemensamma uppfattningar om den andra klassen som pratig.

\section{Coda}

Vardagsberättande avslutas vanligtvis med någon form av avrundning, det Labov (1972) kallar coda, och så även här. Läraren avrundar berättelsen och lämnar över till eleverna genom att kommentera händelseförloppet och ställa autentiska frågor där svaren inte går att finna explicit i berättelsens innehåll.

$41 \mathrm{~L}:$ Då hade vi en tyst minut men efter några...några tiotal sekunder så kunde inte jag hålla mig mer för jag tyckte det var så komiskt å ha en tyst minut för Åke.

Leende med händerna $i$ sidorna. Lyfter höger hand och rör den kupad mot munnen på "jag" och tillbaks i sidan. Nickar efter sista ordet i meningen och gör en kort grimas som här tolkas som en tvekan hon uttrycker nedan.

42 L: (Paus, 0,7 s)

43 L: Det borde jag inte ha tyckt egentligen eller hur? Han var väl värd en tyst minut?

Gär lite àt höger med händerna $i$ sidan.

44 Elever: "Du ba'...du ba'"

Ett par elever härmar när läraren inte kan hälla sig för skratt och mimar bur läraren håller handen för munnen.

45 L: -

Mimar på nytt hur karaktären i berättelsen, hon själv, fnissade med handen framför munnen.

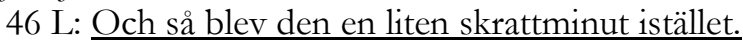

Håller högerband mot sig själv $i$ en svagt pekande gest och gör sedan två snabba cirkelrörelser med höger hand framför kroppen. 


\section{O. HENRICSSON}

Figur 7. Så blev det en liten skrattminut istället.

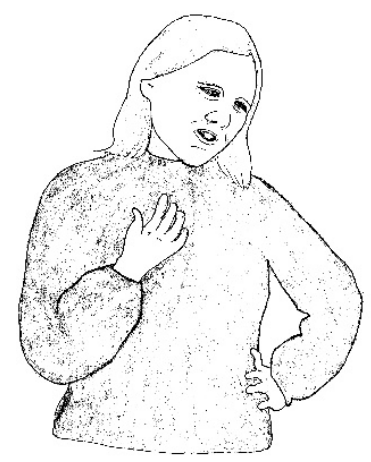

47 L: Så var det.

Med händerna $i$ sidan.

48 E: Vad ospännande!

49 L: (Skrattar) Ja, haha, "ospännande!?”

Gär mot eleven, skrattar och slär lätt med högerhandens fingrar mot elevens bänk på "ospännande".

Figur 8. Ja, haha, "ospännande".

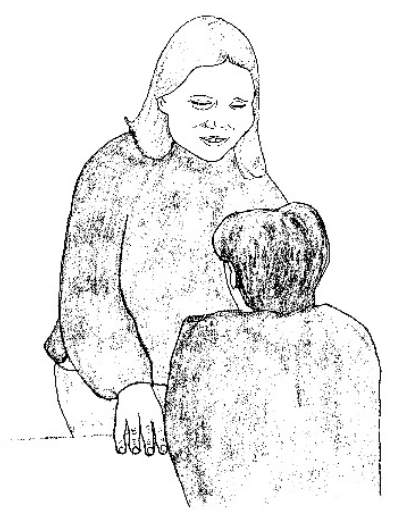

50 E: Skratta åt nån som har dött? 
$51 \mathrm{~L}:$ Ja men... Maria!?

Drar höger hand genom håret och pekar sedan mot elev som räcker upp handen.

Analys: I codan återvänder läraren från berättelsens värld till konversationens rike. Efter en reflekterande tanke, gestaltad som en grimas, ställer läraren ett par autentiska frågor utifrån ett lyssnarperspektiv (Merleau-Ponty, 1999). Det tolkas här dels som ett uttryck för lyhördhet då hon reflekterar över handlingar och händelser i berättelsen utifrån hur det kan uppfattas av lyssnarna, eleverna, dels som en återhållsam undervisning då hon med frågorna öppnar för elevernas tolkningar och åsikter. Ett kort samspel följer där eleverna gestaltar hur läraren inte kunde hålla sig för skratt ( $r a d 44)$ och där läraren själv mimar situationen därefter ( $\mathrm{rad} 45)$. Hon binder avslutningsvis ihop anekdoten med att forma en kortfattad sammanfattning - att istället för en tyst minut blev det en gemensam skrattminut i klassen. Hon bekräftar sanningshalten i berättelsen genom det korta: "Så var det". En elev som då inser att berättelsen är slut utbrister "Vad ospännande!". Läraren avfärdar med att skrattande återupprepa elevens negativa kommentar och lutar sig fram och slår med fingrarna mot elevens bänk. Lärarens lätta touch mot elevens bänk tolkas här som en kommentar eller till och med som en tillrättavisning. Det kan tolkas som att berättandet misslyckas här då eleven är kritisk och hade väntat sig en mer spännande berättelse.

\section{DiSKUSSION}

Vid sidan av att använda berättande som en förberedd metod berättar lärare även spontant som ett svar på elevernas aktiviteter eller kommentarer $\mathrm{i}$ unika undervisningssituationer. Den här typen av gestaltande och improviserad didaktisk handling, i relation till såväl ämnet för undervisningen som till eleverna, har beskrivits som pedagogisk takt. Pedagogisk takt ses här som ett begrepp att beskriva en didaktisk handling som spontant söker balansera undervisningen $\mathrm{i}$ relation till elever såväl som till ämnet (Friesen \& Osguthorpe, 2018). Lärarens berättande kan här tolkas som både lyckat och misslyckat. Hon lyckas fånga elevernas uppmärksamhet och få dem intressserade men berättelsens innehåll går inte explicit att koppla till ämnet för undervisningen vilket kan ses som ett misslyckande. Samtidigt kan lärarens berättande beskrivas som ett pragmatiskt och konventionellt sätt att ta kontroll över situationen och utöva makt. Läraren ger sig själv tolkningsföreträde genom att kort konstatera att händelseförloppet återgavs korrekt med yttrandet "så var det". Att hon kommenterar en elevs negativa kommentar att berättelsen var "ospännande" med en touch med handen på elevens bänk kan tolkas som en tillrättavisning ur ett maktperspektiv. Vid en fördjupad analys pekar lärarens berättande även mot andra didaktiska 
innebörder som i diskussionen nedan beskrivs, utifrån pedagogisk takt, som återhållen undervisning, lyhördhetens oförutsägbarhet och undervisningens risk.

Lärarens berättande takt visar sig som återhållsam undervisning. Samtidigt som läraren blir synlig och tydlig för eleverna med lekfulla och gestaltande gester och miner visar sig berättande, något motsägelsefullt, som didaktiskt återhållsamt. Läraren låter berättelsens händelseförlopp träda i förgrunden och bjuder in eleverna som besökare i upplevelser. Det är för att citera Biesta (2000) som att eleverna ser med "egna ögon från en position som inte är den egna" (s. 84). Berättandet ger dem möjlighet att utifrån sig själva tolka en händelse som de inte själva deltar i. Det vill säga som en icke-påflugen undervisning där läraren inte endast har elevens prestation eller undervisningens mätbara resultat $\mathrm{i}$ åtanke. Vid en jämförelse påminner lärarens berättande takt, och den återhållsamhet som kännetecknar den, det Hopmann (2007) beskriver som "restraint teaching". Hopmann för en diskussion om innehåll kontra mening och menar att i didaktikens kärna ligger en strävan att undervisning ska öppna för elevers meningsskapande (meaning) åt ett specifikt ämnesinnehåll (matter) (s. 115). Att gestalta ett händelseförlopp i berättelsens värld öppnar för eleverna att skapa innebörd av ett innehåll. Det ska inte misstolkas som att berättande och berättelser inte kan vara manipulerande. I den här studien avses själva upplevelsen av berättandet oavsett om berättelsen är att betrakta som god eller inte och i berättarsituationen är man som lyssnare lämnad $\mathrm{i}$ fred tillsammans med andra. Spontant vardagsberättande av minnen eller händelser upplevs inte påfluget som en åsikt eller fördomar och öppnar i stället för en gemensam reflektion över det som hänt (Ochs \& Capps, 2001) vilket synliggörs $i$ den avslutande codan när hon reflekterar och ställer frågor. Hon ger tyvärr inte så mycket utrymme till eleverna att svara i det här utdraget.

Lärares berättande takt visar sig som lyhördhetens oförutsägbarhet. Det går med andra ord inte att förutse exakt hur ett berättande kommer att vävas mellan berättare och lyssnare. Tidigare studier (Henricsson \& Claesson, 2016, 2019) har visat att lärare upplever sitt berättande som en närvaro men samtidigt är lärarens levda kropp (Merleau-Ponty, 1964) transparent för de lyssnande eleverna som riktar sin uppmärksamhet mot berättelsens händelseförlopp. Fångade av berättelsens tid och rum tolkar lyssnare berättarens gester, ansiktsuttryck och hållning som meningsfulla men vi noterar dem inte - "ser" dem inte - som objekt utan som Young (2011) påpekar, som en meningsfull handling. Lärarens levda kropp är verktyget för att levandegöra muntligt berättande men det är inte bara som sändare lärarens levda kropp är närvarande. Från ett lyssnarperspektiv, är det tydligt att hon även är mottagare - lyssnare - själv. Mot slutet av berättarsituationen gestaltas en kort sekunds värdering av berättelsens innehåll som en grimas innan hon berättar vidare. Med Merleau-Pontys (1999) ord så lyssnar hon till berättandet 
utifrån den andre - hon "hör sig själv i den andre" (s. 47). Hon undersöker berättelsens mening på nytt när berättelsens dåtid levandegörs i ett berättande nu och som i sin tur alltid är riktat mot framtiden (Ochs \& Capps, 2001). Taktfullt didaktiskt handlande visar sig i kroppen såväl som språket. Lärarens lyhördhet visar sig när hon ler och skrattar åt elevens negativa yttrande. Hon tillrättavisar inte elevens åsikt samtidigt markerar hon genom att toucha elevens bänk med en mjuk handrörelse. Det tolkas här som en respektfull markering och kanske till och med, utifrån lärarens skratt, som en ömsesidig uppfattning att berättelsen inte var särskilt spännande. Kroppen signalerar hennes inställning och visar sig här som både sändare och mottagare. Lyhördhetens oförutsägbarhet får didaktiska innebörder då den berättande läraren balanserar i den didaktiska triangeln (Friesen \& Osguthorpe, 2018) genom att dels ta ansvar för berättelsens begriplighet utifrån samspelet med eleverna, dels är öppen för den unika tolkningen och kritik i mötet med eleverna. Det finns en risk att berättande tar fokus från ett specifikt ämnesinnehåll men det kan samtidigt finnas didaktiska poänger med risker.

Lärares berättande takt visar sig som en undervisningens risk. Det går med andra ord inte att veta vad som kommer ut av berättandet. Risken gestaltas dels $\mathrm{i}$ förhållande till ämnet då berättelsens innehåll snarare beskriver en komisk och rörande undervisningssituation än att den illustrerar det ämnesinnehåll som berättelsen inledningsvis länkades till. Dels att berättandets ömsesidighet visar sig $\mathrm{i}$ att mening skapas i berättarsituationen, enligt Young (2000), och att till och med läraren själv reflekterar med en genuin fråga om hennes agerande som karaktär i berättelsen var lämpligt. Eleverna interagerar också genom att undersöka lärarens förslag på berättelsens innebörd att det blev en "skrattminut istället för tyst minut" genom att mima hur läraren bryter tystnaden genom att skratta. Friheten och risken med spontant muntligt berättande är att det svårligen går att pressa in som ett föreskrivet innehåll i en läroplan eller som förutsägbara steg i en steg-för-stegmetod. En berättande takt ställer däremot krav på lärarens situationstrygghet att vara naturlig och fri i sitt spontana didaktiska handlande. Det står i kontrast till den instrumentella synen på undervisning och lärande, där en viss metod leder till ett på förhand givet generaliserbart utfall. En berättande takt gör elevernas självverksamhet och medskapande tillgängligt bortom pressen på att producera generella mätbara resultat. I lärarens berättande visar sig undervisningens risk, enligt Biesta (2013), samtidigt som en undervisningens möjlighet.

\section{KONKLUSION}

Muntligt berättande riktar elevernas uppmärksamhet från observerbara faktiska föremål, modeller och förhållanden till narrativa metaforer och händelseförlopp som skapas av elevernas föreställningsförmåga. Det gör det 
till en oförutsägbar och riskfylld undervisning som öppnar för taktfullt didaktiskt handlande. Läraren $\mathrm{i}$ studien hade inte förberett att berätta anekdoten och ifrågasatte huvudkaraktärens, sitt eget, handlande. Det förefaller på det hela taget väldigt improviserat och spontant och för en observatör vara utan annan poäng än att fånga elevernas uppmärksamhet med en komisk anekdot. Det är så här undervisning visar sig emellanåt, irrationell och oförutsägbar, men det behöver inte betyda att den är dålig - tvärtom. Här bör man vara ödmjuk och inse att det är omöjligt att fånga alla subtila kausala och koherenta aspekter av berättande i en grupp som man inte själv tillhör. Det kan vara betydelsefullt, för den här läraren och de här eleverna, att dela en rörande och komisk situation i elevernas och lärarens gemensamma livsvärld. Om en lärare endast förväntas använda sig av metoder som leder till att eleverna presterar något som går att mäta så förbises avgörande didaktisk erfarenhet och kunskap om muntligt berättande. Jackson (1995) menar att en lärares förhoppning med sitt berättande är att det ska komma något gott ur det men samtidigt skulle de få svårt att säga exakt vad det där goda innebär. Han väcker frågan om lärare bara ska berätta då de vet vad de gör eller om man ska uppmuntra lärare att berätta även när funktionen är oklar och resultatet förblir omätbart (s. 22).

Går det att lära sig en berättande takt? Herbart uttryckte det som att den lärare som alltför strikt följer en teori eller metod ovillkorligen kommer att bli varse att "de praktiska omständigheterna kommer att förvilla honom" (Friesen, 2020, s. 6). Det handlar snarare om att förbereda sig på situationstryggheten eller, som Westfall-Greiter och Schwarz (2012) uttryckte det, att planera för det som är möjligt att planera men samtidigt "förvänta sig det oförväntade" (s. 132). Studiens bidrag att empiriskt synliggöra förkroppsligad pedagogisk takt som berättande takt skulle kunna vara att ge underlag till lärare och lärarstudenter att reflektera över dess didaktiska innebörder.

\section{NOTER}

${ }^{1}$ Översatta citat i artikeln är egna översättningar från engelska, tyska eller danska.

${ }^{2}$ Att Herbart lanserade begreppet 1802 innebär inte att takt som fenomen uppfanns då. Tankar om lärares improviserade handlande uttrycktes långt tidigare, för att nämna bara en beskrev läraren Johannes Buna på 1600-talet, det då begreppslösa, fenomenet som att: "en klok lärare vet hur man anpassar sin personlighet, timing och möjlighet" (Muth, 1962, s. 8).

${ }^{3}$ Med utgångspunkt i den tyska kontinentala didaktiska traditionen med Pestalozzi, Kant, Schleiermacher och Herbart.

${ }^{4}$ Feingefühl skulle kunna översättas till svenska som finkänslighet men jag anser att lyhördhet bättre beskriver ordets pedagogiska innebörd.

${ }^{5}$ Zurückhaltung.

${ }^{6}$ Understrykning i transkriptionen visar under vilken sekvens läraren utför de beskrivna gesterna. 


\section{REFERENSER}

Aasebø, Turid S., Midtsundstad, Jorunn H., \& Willbergh, Ilmi (2017). Teaching in the age of accountability: restrained by school culture?. Journal of curriculum studies, 49(3), 273-290. http://doi.org/10.1080/00220272.2015.1072249

Alexander, Robin (2001). Culture and pedagogy: International comparisons in primary education. Blackwell.

Andrews, Molly, Squire, Corinne, \& Tamboukou, Maria (red.) (2008). Doing narrative research. Sage.

Bamberg, Michael, \& Demuth, Carolin (2016). Narrative inquiry: An interview with Michael Bamberg. Europe's Journal of Psychology, 12(1), 14-28. http://doi.org/10.5964/ejop.v12i1.1128

Barkhuizen, Gary, Benson, Phil, \& Chik, Alice (2014). Narrative inquiry in language teaching and learning research. Routledge.

Bellack, Arno A., Kliebard, Herbert M., Hyman, Ronald T., \& Smith, Frank L. (1966). The language of the classroom. Teacher College Press.

Bengtsson, Jan (1999). En livsvärldsansats för pedagogisk forskning. I J. Bengtsson, Med livsvärlden som grund (s. 9-58). Studentlitteratur.

Biesta, Gert (2000). Om att vara med andra - Pedagogikens svårighet såsom politikens svårighet. Utbildning \& demokrati, 9(3), 71-89.

Biesta, Gert (2012). No education without hesitation: exploring the limits of educational relations. Keynote address to the society for the Philosophy of Education. Philosophy of Education.

Biesta, Gert (2013). The beautiful risk of education. Paradigm Publishers.

Bolkan, San, Goodboy, Alan K., \& Kromka, Stephen M. (2020). Student assessment of narrative: telling stories in the classroom. Communication Education, 69(1), s. 4869. http://doi.org/10.1080/03634523.2019.1622751

Claesson, Silwa, \& Rinne, Ilona (2019). Vägskäl och ställningstagande i didaktiska studier. I I. Berndtsson, A. Lilja, \& I. Rinne (red.), Fenomenologiska sammanflätningar (s. 155-179). Daidalos.

Colnerud, Gunnel (1997). En omöjlig jämförelse. Pedagogisk forskning i Sverige, 2(2), 95-104.

Derry, Sharon J. (2007). Guidlines for video research in education: Recommendations from an expert panel. Data research and development center.

Eriksson, Inger (1999). Lärares pedagogiska handlingar: en studie av lärares uppfattningar av att vara pedagogisk $i$ klassrumsarbetet. [Doktorsavhandling, Uppsala universitet]. 
Friesen, Norm (2017). The pedagogical relation past and present: experience, subjectivity and failure. Journal of curriculum studies, 49(6), 743-756. http://doi.org/10.1080/00220272.2017.1320427

Friesen, Norm (2018). Embodying tact in teaching: ineluctable ambivalence, sensitivity, and reserve. Philosophy of education, 1(2018), 301-309.

Friesen, Norm (2020). Herbart - Introductory lecture to students in pedagogy. (Opublicerat artikelmanus).

Friesen, Norm, \& Osguthorpe, Richard (2018). Tact and the pedagogical triangle: The authenticity of teachers in relation. Teaching and teacher education, 70(2018), 255264. http://doi.org/10.1016/j.tate.2017.11.023

Henricsson, Ola, \& Claesson, Silwa (2016). Teachers' experiences of telling stories in primary and lower secondary Swedish classrooms. I H. Höglund \& R. HeliäYlikallio (red.), Framtida berättelser - perspektiv på nordisk modersmålsdidaktisk forskning och praktik (s. 29-45). Rapport från fakulteten för pedagogik och välfärdsstudier vid Åbo Akademi (2016:39).

Henricsson, Ola, \& Claesson, Silwa (2019). Everyday storytelling in teaching Indian teachers' experiences of telling stories in teaching. Storytelling, Self, Society. 15 (2), 242-269. https://www.jstor.org/stable/10.13110/storselfsoci.15.2.0246

Hopmann, Stefan (2007). Restrained teaching: the common core of Didaktik. European Educational Research Journal, 6(2), 109-124. http://doi.org/10.2304/eerj.2007.6.2.109

Hydén, Lars-Christer (2008). Bodies, embodiment and stories. I M. Andrews, C. Squire, \& M. Tamboukou (red.), Doing narrative research (s. 126-141). Sage.

Jackson, Philip W. (1995). On the place of Narrative in Teaching. I H. McEwan, \& K. Egan (red.), Narrative in teaching, learning, and research (s. 3-23). Teachers College Press.

Koerrenz, Ralf (2017). Existentialism and education - an introduction to Otto Friedrich Bollnow. Springer International Publish.

Kromka, Stephen M., Goodboy Alan K., \& Banks, Jaime (2020). Teaching with relevant (and irrelevant) storytelling in the college classroom. Communication Education. 69(2), 224-249. http://doi.org/10.1080/03634523.2019.1657156

Labov, William (1972). Language in the Inner City: Studies in the Black English Vernacular. University of Pennsylvania

Lwin, Soe M. (2016). "It's story time!: exploring the potential of multimodality in oral storytelling to support children's vocabulary learning”. Literacy, 50(2), 72-82.

McEwan, Hunter, \& Egan, Kieran (red.) (1995). Narrative in teaching, learning, and research. Teachers College Press.

McNeill, David (1992). Hand and mind: what gestures reveal about thought. University of Chicago Press. 
Mehan, Hugh (1979). Learning lessons: Social organization in the classroom. Harvard University Press.

Merleau-Ponty, Maurice (1964). The primacy of perception. Northwestern University Press.

Merleau-Ponty, Maurice (1968). The visible and the invisible. Northwestern University Press.

Merleau-Ponty, Maurice (1999). Om sprogets fanomenologi: utvalgte tekster. Gyldendal.

Muth, Jacob (1962). Pädagogischer Takt: Monographie einer aktuellen Form erzieherischen und didaktischen Handelns. [Doktorsavhandling, Heidelberg University]. Quelle \& Meyer.

Ochs, Elinor (1997). Transcription as theory. I E. Ochs \& B. B. Schieffelin (red.), Developmental Pragmatics (s. 43-72). Adademic Press.

Ochs, Elinor, \& Capps, Lisa (2001). Living narrative: Creating lives in everyday storytelling. Harvard University Press.

Oettingen, Alexander V. (2018). Allmän didaktik: mellan normativitet och evidens. Studentlitteratur.

Palmenfelt, Ulf (2006). Från tre världar till många - tankar om berättandets etnografi. Kulturella perspektiv, 15(3), 4-13.

Ricœur, Paul (1980). Narrative time. Critical Inquiry, 7(1), 169-190.

Riessman, Catherine K. (1993). Narrative analysis. Sage.

Roth, Wolff-Michael (2001). Gestures: Their role in teaching and learning. Review of Educational Research, 71(3), 365-392. http://doi.org/10.3102/00346543071003365

Rödel, Severin S., \& Brinkmann, Malte (2018). Theory and methodology of pedagogical-phenomenological video analysis. Video journal of education and pedagogy, 3(10), 1-25. http://doi.org/10.1186/s40990-018-0023-1

Schratz, Michael, Schwarz, Johanna F., \& Westfall-Greiter, Tanja (2012). Lernen als bildende Erfahrung: Vignetten in der Praxisforschung. Studienverlag.

Tjärnstig, Leif (2020). Didaktisk praxis i waldorfskolan: en didaktisk analys och bildningsteoretisk tolkning av fyra waldorflärares pedagogiska tänkande och förhållningssätt. [Doktorsavhandling, Åbo akademi].

van Manen, Max (1991). The tact of teaching: The meaning of pedagogical thoughtfulness. State University of New York Press.

van Manen, Max (2014). Phenomenology of practice: Meaning-given methods in phenomenological research and writing. Left Coast Press.

van Manen, Max (2015). Pedagogical tact: knowing what to do when you don't know what to do. Left Coast Press.

Vetenskapsrådet (2017). God forskningssed [Elektronisk resurs]. (Reviderad utgåva). Vetenskapsrådet. 
Westfall-Greiter, Tanja, \& Schwarz, Johanna F. (2012). Planning for the unplannable: Responding to (un)articulated calls in the classroom. Phenomenology \& Practice, 6(2), 121-135. http://doi.org/10.29173/pandpr19866

Young, Katharine (1987). Taleworlds and storyrealms: The Phenomenology of Narrative. Martinus Nijhoff Publishers.

Young, Katharine (2000). Gestures and the phenomenology of emotion. Narrative Semiotica, 131(1/2), 79-112. http://doi.org/10.1515/semi.2000.131.1-2.79

Young, Katharine (2011). Gestures, Intercorporeity, and the Fate of Phenomenology in Folklore. Journal of American Folklore, 124(492), 55-87. http://doi.org/10.5406/jamerfolk.124.492.0055

Xueping, Li (2012). Effects of Negotiated Interaction on Mongolian-nationality EFL Learners' Spoken Output. English Language Teaching, 5(6), 119-134. http://doi.org/ 10.5539/elt.v5n6p119 